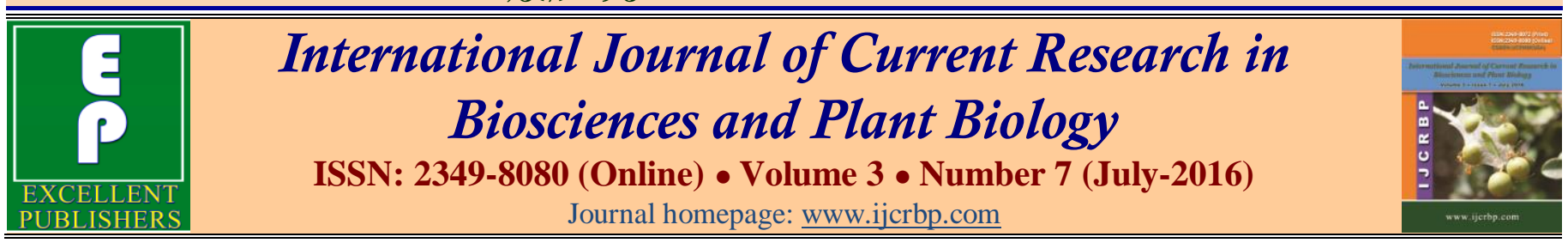

\title{
Effects of Proline Content of Green Gram Varieties/Lines as Influenced by Root-Knot Nematode, Meloidogyne incognita
}

\author{
Ritu Kumari Pandey ${ }^{1}$, D. K. Nayak ${ }^{2 *}$ and Rajesh Kumar Kar ${ }^{1}$ \\ ${ }^{1}$ Ph.D. Scholars, Department of Nematology, College of Agriculture, Orissa University Of Agriculture \& Technology, \\ Bhubaneswar-3 Orissa, India \\ ${ }^{2}$ Associate Professor, Department of Nematology, College of Agriculture, Orissa University Of Agriculture \& Technology, \\ Bhubaneswar-3 Orissa, India \\ *Corresponding author.
}

\begin{abstract}
The variation in total proline content in six greengram cultivars i.e., 24 ML-233 (R), 7 GGG 10-14 (R), 17 IPM 9901-6 (R), 8 GM 04-02 (R), 28 PM 10-12(S) and 29 PUSA 0672 (S) were studied 45 days after inoculation of Meloidogyne incognita. The total proline content in the shoots of both healthy and resistant cultivars was higher compared to the susceptible cultivars. However, in the inoculated plants the total proline content in four resistant variety varied from $100 \mathrm{mg} / \mathrm{g}$ to $150 \mathrm{mg} / \mathrm{g}$ as compared to two susceptible variety $(90 \mathrm{mg} / \mathrm{g}$ to $140 \mathrm{mg} / \mathrm{g}$ ). An increasing trend was also observed in the proline contents in the shoots of inoculated susceptible and resistant cultivars.
\end{abstract}

\section{Article Info}

Accepted: 09 June 2016

Available Online: 06 July 2016

Keywords

Biochemical modifications

Green gram cultivars

Meloidogyne incognita

Proline content

\section{Introduction}

Green gram is commonly known as mung bean or moong [Vigna radiata (L.) Wilezek] is an important pulse crop next to chickpea and pigeon pea in India. Being one of the major pulse crop of the Fabaceae family it is a rich source of dietary protein $(22.9 \%)$, carbohydrate $(62.8 \%)$, fat $(1.2 \%)$, minerals $(3 \%)$ and fibre $(1 \%)$ and also it has considerable amount of calcium $105 \mathrm{mg}$, phosphorous $330 \mathrm{mg}, \mathrm{Fe}$, ashes, etc. The major causes of low productivity are the incidence of insects and diseases including plant parasitic nematodes. Plant parasitic nematode, Meloidogyne incognita alters the metabolic processes of the host which are manifested in the form of cellular, physiological and biochemical changes occurring in the infected host. The root-knot nematodes cause measurable changes in the morphology and physiology of the host plants (Williamson and Gleason, 2003).
Bird and McClure (1976), in their chemical analysis of the hydrolysis products of the egg shells of $M$. javanica, Rotylenchulus reinformis, Pratylenchus minyus and Tylenchulus semipenetrans have revealed a high proline content (up to $25 \%$ ) which is apparently a characteristic of nematode egg shells.

Nasar et al. (1980) analysed the effect of root-knot nematodes on the amino acid concentration of almond and peach root stalks and reported that the combined amino acid content of roots and leaves of bitter almond and Nemagaurd peach plants were the same in control and infested plants. The free amino acid threonine was absent in $M$. incognita infested almond leaves and proline was present only in $M$. incognita infested roots and leaves of almond.

Okie and Reilly (1984) studied the effect of the ring nematode, Criconemella xenoplax on physiology of peach 
root stocks and reported reduced free amino acids in shoots and roots as measured by levels of ninhydrin reactive compounds. They also found that the proportions of specific amino acids were changed and the molar percentage of proline, glycine and alanine increased, whereas arginine decreased in roots of both seedlings and herbaceous cuttings in the presence of nematode.

Bio-chemical alterations brought about in Abelmoschus esculentus as a result of root knot nematode infection was estimated by Trivedi and Sharma (1996) in roots uprooted after 30, 60 and 90 days of $M$. incognita inoculation. Quantitative analysis for different metabolites in both highly susceptible (Pusa Sawani) and less susceptible (Punjab 7) cultivars showed reduction in sugar, proteins, total free amino acids, proline, phenols, ascorbic acid, enzyme, nitrogen and sodium excepting total sugars, non-reducing sugar, phosphorus and potassium which were found to be increasing in diseased roots of both the okra cultivars over their healthy counterparts.

The appearance of L-proline only in nematode infected samples of both susceptible and resistant variety during post infection period is in accordance with the findings of earlier workers (Lewis and Mc Clure, 1975; Mohanty and Das, 1976; Mohanty and Pradhan, 1990; Mishra and Mohanty, 2007). The high metabolic activity in roots associated with giant cells and gall formation as well as egg-production exerts a requirement for energy which is supplied by a free proline manufactured in the leaves and translocated to the site of nematode infection. Besides, the ratio of L-proline and hydroxyl proline play key role in imparting susceptible and resistant reactions and always associated with the stress condition of the host plant. Decrease in arginine content in both the varieties during post-infection period possibly due to conversion of L-arginine to L-proline through ornithine cycle.

\section{Materials and methods}

Exactly 200mgs of leaf was macerated with $5 \mathrm{ml}$ of sulfo salicylic acid. The residue was centrifuged at 4000 r.p.m. for 15 minutes. The supernatant liquid was decanted to a $50 \mathrm{ml}$ test tube. Five $\mathrm{ml}$ of glacial acetic acid and $5 \mathrm{ml}$ of acid ninhydrin was added to it. The mouth of the test tube was closed by polythene paper and rubber band. It was boiled for $1 \mathrm{hr}$. in water bath at $100^{\circ} \mathrm{C}$. After boiling of standards and sample, the reaction mixture was transferred to $60 \mathrm{ml}$ separating funnels. $20 \mathrm{ml}$ of toluene was added and shaken vigorously. It was then allowed to settle. The chromophore containing toluene was separated out through the bottom hole of the separating funnels. Absorbance was measured at $520 \mathrm{~nm}$. By the help of standard curve data, the amount of proline present in plant sample was calculated and expressed as mg proline/gram of fresh sample.

\section{Results and discussion}

In order to know the chemical and genetic basis of resistance, six varieties were grown with utmost care, both in inoculated and control conditions.

\section{Effect of nematode infection on proline content}

The proline content of healthy plants of green gram cultivars were $130,40,60,60,70$ and $100 \mathrm{mg} / \mathrm{g}$ in 28 PM 10-12, 29 PUSA 0672, 24 ML-233, 7 GGG 10-14, 17 IPM 9901-6 and 8 GM 04-02 respectively. Due to the infection of root knot nematode the proline contents of these varieties increased by $7.69,125,83.33,100,42.85$ and 50\% respectively (Table 1 and Fig. 1). The presence of L-proline in inoculated samples of both susceptible and resistant varieties during post infection period is in accordance with the findings of earlier workers (Lewis and Mc Clure, 1975; Mohanty and Pradhan, 1990).

Table 1. Percentage increase /decrease in proline content in healthy $(\mathrm{H})$ and root-knot infected (I) plant.

\begin{tabular}{|c|c|c|c|c|c|}
\hline \multirow{3}{*}{ Sl. No. } & \multirow{3}{*}{ Variety } & \multicolumn{4}{|c|}{ Proline content mg/g on fresh weight basis } \\
\hline & & \multicolumn{3}{|c|}{ Infected Healthy $\quad$ Mean } & \multirow{2}{*}{$\begin{array}{l}\% \text { increase }(+) / \text { decrease }(-) \\
\text { over control }\end{array}$} \\
\hline & & Leaf & Leaf & Leaf & \\
\hline 1 & 28 PM 10-12 & 140 & 130 & 135 & 7.69 \\
\hline 2 & 29 PUSA 0672 & 90 & 40 & 65 & 125 \\
\hline 3 & $24 \mathrm{ML}-233$ & 110 & 60 & 85 & 83.33 \\
\hline 4 & 7 GGG $10-14$ & 120 & 60 & 90 & 100 \\
\hline 5 & 17 IPM 9901-6 & 100 & 70 & 85 & 42.85 \\
\hline \multirow[t]{3}{*}{6} & 8GM 04-02 & 150 & 100 & 125 & 50 \\
\hline & $\operatorname{SEM}( \pm)$ & 24.72 & 25.08 & & \\
\hline & CD (0.05) & 77.87 & 79.01 & & \\
\hline
\end{tabular}




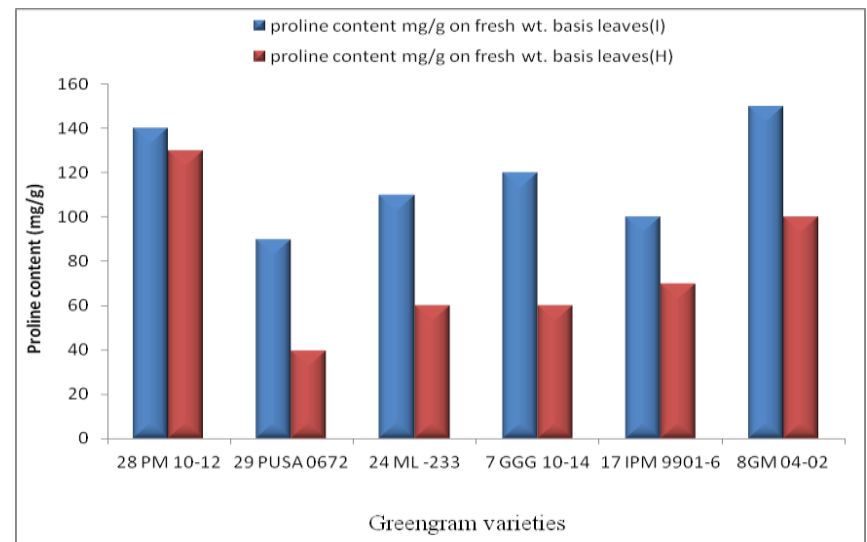

Fig. 1: Proline content of infected and control plants on fresh wt. basis.

\section{Effects on proline substance}

The proline content of the infected plants was found to be increased which is in conformity with the findings of Lewis and McClure (1975), Meon et al. (1978) and, Mohanty and Pradhan (1990). It was also observed that proline content of infected susceptible cultivars increased with time but highest proline content was found in nematode infected (healthy leaf) of resistant cultivars. The variation in total proline content in six green gram cultivars, 24 ML-233 (R), 7 GGG 10-14 (R), 17 IPM 9901-6 (R) ,8 GM 04-02 (R), 28 PM 10-12(S) and 29 PUSA $0672(\mathrm{~S})$ were studied 45 days after inoculation of Meloidogyne incognita. The total proline content in the shoots of both healthy and resistant cultivars was higher compared to the susceptible cultivars. However, in the inoculated plants the total proline content in four resistant varieties varied from 100 $\mathrm{mg} / \mathrm{g}$ to $150 \mathrm{mg} / \mathrm{g}$ as compared to two susceptible varieties $(90 \mathrm{mg} / \mathrm{g}$ to $140 \mathrm{mg} / \mathrm{g})$.

\section{Conclusion}

Some selective changes occur in the metabolism either as a consequence of the establishment of a compatible (susceptible) host-pathogen interaction or as a result of incompatibility (resistant) between host and parasite. There is some knowledge of biochemical changes that occurs in plants following nematode attack that has not been extended to an overall interpretation of the defense mechanism. The root-knot nematode develops a sophisticated interrelationship with the roots of their host where they induce specific types of nurse cell system. The total proline content of four resistant varieties of green gram varied from $100 \mathrm{mg} / \mathrm{g}$ to $150 \mathrm{mg} / \mathrm{g}$ as compared to two susceptible varieties $(90 \mathrm{mg} / \mathrm{g}$ to 140 $\mathrm{mg} / \mathrm{g}$ ). An increasing trend was also observed in the proline contents in the shoots of inoculated susceptible and resistant cultivars. The above findings are in agreement with the findings of Nayak (2006) while analyzing the biochemical variations of various metabolites as influenced by Meloidogyne incognita in susceptible and resistant brinjal cultivars.

\section{Conflict of interest statement}

Authors declare that they have no conflict of interest.

\section{Acknowledgement}

Authors are thankful to those who helped in the chemical analysis of plant samples for different parameters and Project Co-ordinator and Principal Scientist (Nematology), IIPR, Kanpur for providing seed materials to conduct this investigations.

\section{References}

Bird, A. R., McClure, M. A., 1976. The tylenchid (Nematoda) egg shell, structure, composition and permeability, Parasitol. 72(1), 19-28.

Lewis, S. A., McClure, M. A., 1975. Free amino acids in roots of infected cotton seedlings resistant and susceptible to Meloidogyne incognita. J. Nematol. 7(1), 10-15.

Moen, S., Fisher, J.M., Wallace, H.R., 1978. Changes in free praline following infection of plant with either Meloidogyne incognita or Agrobacterium tumefaciens. Physiol. Plant Pathol. 12, 251-256.

Mishra, C. D., Mohanty, K. C., 2007. Change in amino acid content in rice plants due to infection of Meloidogyne graminicola. J. Res. Orissa Univ. Agric. Technol. 25(1), 87-91.

Mohanty, K. C., Pradhan, A. K., 1990. Qualitative determination of free aminoacids and amides in resistant and susceptible green varieties inoculated with root-knot nematode, Meloidogyne incognita. Comp. Physiol. Ecol. $15,9-12$.

Mohanty, K. C., Das, S. N., 1976. Free amino acids in the roots of finger millet plants infected with ring nematodes, Indian Phytopath. 29(4), 434-436.

Nasar, T. A., Ibrahin, I. K. A., Elazab, E. M., Hasan, M. W. A., 1980. Effect of root-knot nematodes on the mineral, aminoacid and carbohydrate concentration of almond and peach root stocks. Nematogica. 26, 133-138.

Nayak, D. K., 2006. Biochemical evaluation of various metabolites as influenced by root-knot nematode, Meloidogyne incognita in susceptible and resistant brinjal cultivars. A Ph.D. Thesis submitted to Orissa University of Agriculture and Technology, Bhubaneswar, Orissa.

Okie, W. R., Reilly, C. C., 1984. Effect of the ring nematode on growth and physiology of peach root-stocks under green house conditions. Phytopathol. 74(1), 1304-1307. 
Trivedi, P. C., Sharma, W., 1996. Biochemical evaluation of various metabolites as influenced by root-knot nematode in Abelmoshchus esculentus. Ind. J. Nematol. 26(2), 150157.
Williamson, V. M., Gleason, C. A., 2003. Plant-nematode interactions, Curr. Opinion Plant Biol. 6(4), 327-333.

\section{How to cite this article:}

Pandey, R. K., Nayak, D. K., Kar, R. K., 2016. Effects of proline content of green gram varieties/lines as influenced by root-knot nematode, Meloidogyne incognita. Int. J. Curr. Res. Biosci. Plant Biol. 3(7), 29-32. doi: http://dx.doi.org/10.20546/ijcrbp.2016.307.005 